\title{
Original Paper \\ Karyotypic analyses and genomic affinity among Argentinean species of Passiflora
}

\author{
Verónica Lucía Bugallo ${ }^{1,2,5,6}$, María Florencia Realini ${ }^{3,4}$, Gabriela Rosa Facciuto ${ }^{2}$ \& Lidia Poggio Li,4 $^{3,4}$
}

\begin{abstract}
The genus Passiflora (Passifloraceae) has more than 500 species, nineteen are native to Argentina. By their austral distribution, these species were included in breeding programs to obtain ornamental varieties tolerant to low temperatures. The aim of this work was to know the cytogenetic characteristics of Passiflora genotypes present in a working collection, as an indispensable knowledge for the development of a breeding plan. Chromosomal preparations were performed and karyotypic characteristics, rDNA sites by FISH and affinity among subgenera by GISH were studied. Chromosome counts in fourteen Argentinean species confirmed the basic chromosome numbers previously published: $\mathrm{x}=6$ for subgenus Decaloba, $\mathrm{x}=9$ for subgenus Passiflora and $\mathrm{x}=10$ for Dysosmia. The karyotypic parameters (karyotype, haploid chromosome length and asymmetry indices) and genomic affinities among the subgenera, clarify most of the chromosomal evolution of the genus. The results obtained strongly suggest that the basic number $\mathrm{x}=6$ would be the original one and that $\mathrm{x}=9$ was originated by processes of polyploidy and descendent dysploidy. Since subgenus Passiflora possesses the largest genomes, it is postulated that evolutionary process leading to $\mathrm{x}=9$ was accompanied by unequal distribution of non-coding repetitive DNA, mainly transposable elements. These processes could explain the asymmetrical karyotypes of species of subgenus Passiflora.

Key words: chromosome numbers, in situ hybridization, karyotypes, native Passiflora to Argentina, ornamental plant breeding.

\section{Resumen}

El género Passiflora (Passifloraceae) cuenta con más de 500 especies, diecinueve de ellas son nativas de Argentina. Por su distribución austral, estas especies fueron incluidas en un plan de mejoramiento para obtener variedades ornamentales tolerantes a bajas temperaturas. El objetivo de este trabajo fue conocer las características citogenéticas de los genotipos de Passiflora en la colección de trabajo como conocimiento indispensable para el desarrollo de un plan de mejoramiento. Se realizaron preparados cromosómicos y se estudiaron las características cariotípicas, regiones ADNr por FISH y afinidad genómica entre subgéneros por GISH. Los recuentos cromosómicos realizados en catorce especies argentinas confirmaron los previamente publicados: $\mathrm{x}=6$ para el subgénero Decaloba, $\mathrm{x}=9$ para el subgénero Passiflora y $\mathrm{x}=10$ para el subgénero Dysosmia. Los parámetros cariotípicos (cariotipos, longitud del genoma haploide e índices de asimetría) y las afinidades genómicas analizadas por GISH entre las especies de los tres subgéneros, clarifican la mayor parte de la evolución cromosómica del género. Los resultados obtenidos sugieren que el número básico $\mathrm{x}=6$ sería el original y que $\mathrm{x}=9$ se habría originado por procesos de poliploidía y disploidía descendente. Debido a que las especies del subgénero Passiflora poseen los genomas más largos, se postula que el proceso evolutivo que llevó de $\mathrm{x}=10 \mathrm{ax}=9$ fue acompañado por una distribución desigual en los brazos cromosómicos de $\mathrm{ADN}$ repetitivo no codificante, principalmente elementos transponibles. Estos procesos explicarían la asimetría cariotípica del subgénero Passiflora.

Palabras clave: números cromosómicos, hibridación in situ, cariotipos, especies de Passiflora nativas de Argentina, mejoramiento genético de ornamentales.

\footnotetext{
${ }^{1}$ Universidad de Buenos Aires, Facultad de Agronomía, Av. San Martín 4453, Ciudad Autónoma de Buenos Aires, Argentina.

${ }^{2}$ Instituto Nacional de Tecnología Agropecuaria (INTA), Instituto de Floricultura, De los reseros y Nicolás Repetto s/n, Hurlingham, Buenos Aires, Argentina.

${ }^{3}$ Universidad de Buenos Aires, Depto. Ecología, Genética y Evolución, Facultad de Ciencias Exactas y Naturales, Lab. Citogenética y Evolución (LaCyE), Intendente Güiraldes 2160, Ciudad Universitaria, Ciudad Autónoma de Buenos Aires, Argentina.

${ }^{4}$ Instituto de Ecología, Genética y Evolución (IEGEBA), Consejo Nacional de Investigaciones Científicas y Técnicas (CONICET), Ciudad Autónoma de Buenos Aires, Argentina.

${ }^{5}$ ORCID: <https://orcid.org/0000-0003-0079-5301>

${ }^{6}$ Author for correspondence: bugallo@agro.uba.ar, bugallo.veronica@inta.gob.ar
} 


\section{Introduction}

The genus Passiflora L. (Passifloraceae) has more than 500 species; most of this diversity is found in South America. Fruits of some Passiflora species are edible, such as passion fruit (P. edulisf. flavicarpa $\mathrm{O}$. Deg.), others species have medicinal properties ( $P$. incarnata L.) and many of them are cultivated for their ornamental characteristics $(P$. alata Curtis). The versatility of the species of this genus highlights their potential as source of traits for plant breeding.

There are nineteen species of Passiflora reported as native to Argentina (Deginani 2001). Due to their taxonomic characteristics, the Argentinean species were divided in four subgenera: Passiflora (11 species), Tacsonioides (1), Dysosmia (2) and Decaloba (5) (Deginani 2001). The austral distribution of the Argentinean taxa, postulates them as tolerant to temperate environments, unlike most species of the genus that prefer tropical climates. For this reason, fourteen of these species present in the collection of the Institute of Floriculture (INTA, Buenos Aires) were included in a breeding program that aim to obtain ornamental varieties tolerant to low temperatures by means of interspecific hybridization (Bugallo et al. 2011). So far, hybrids were only obtained among some of the Passiflora subgenera species while none of the inter-subgenera crossings tested thrived (unpublished data).

The basic chromosome numbers reported for the subgenera were $\mathrm{x}=9$ for Passiflora and Tacsonioides, $\mathrm{x}=10$ for Dysosmia and $\mathrm{x}=6$ for Decaloba (Souza et al. 2008; Melo et al. 2001). The study of the variability of the DNAr sites that more quantity of Argentine species approached was the one of Melo \& Guerra (2003), where ten of the species were included. According to phylogenetic studies, the basic numbers would support the monophyly of each subgenus (Muschner et al. 2003). Despite the morphological and cytogenetic differences, the molecular studies indicate that subgenera Passiflora and Dysosmia would be more related with each other and less with subgenus Decaloba (Sader et al. 2019; Muschner et al. 2003).

The aim of this work was to know the cytogenetic characteristics of the Passiflora species present in the working collection of the Institute of Floriculture (INTA - National Institute of Agricultural Technology, Argentina), as an indispensable knowledge for the development of a breeding plan to obtain tolerant to low temperatures plants. The breeding plan in Passiflora is included in a bigger project that aim to obtain ornamental varieties from native species to Argentina. For this reason, cytogenetic characterization of the 49 genotypes belonging to fourteen Argentinean Passiflora species, including fluorescent chromosome staining (DAPI) and in situ hybridization (FISH), using rDNA $18 \mathrm{~S}$ and $5 \mathrm{~S}$ as probes were performed. The chromosome counts and karyotypes provided new data and corroborated existing information. Furthermore, we explore the genomic affinity among the three subgenera by means of GISH assays, unsuccessfully inter-hybridized until now.

\section{Materials and Methods}

Plant material

For the cytological studies, the 49 genotypes of fourteen species of Passiflora present in the Institute of Floriculture (INTA - National Institute of Agricultural Technology, Argentina). These plants were the same used in the breeding program to obtain ornamentals from native species. The genotypes and their origin sites were listed in Table 1.

\section{Chromosomal preparations}

Mitotic metaphase preparations were performed in the fourteen species (Tab. 1). Fixed root tips were treated with an enzymatic solution ( $2 \%$ cellulase Onozuka R 10 and $20 \%$ Pectinase) for $1 \mathrm{~h}$ at $37^{\circ} \mathrm{C}$. Slides with well-spread metaphases were selected by contrast-phase microscopy. The coverslips were removed by freezing on dry ice and the slides were air-dried and stored at $4{ }^{\circ} \mathrm{C}$ until use.

DAPI staining (4',6-Diamidino-2phenylindole)

The DAPI staining technique was applied, according to Sumner (1990). Slides were washed in McIlvaine buffer (citric acid-NaHPO buffer, $\mathrm{pH}$ 7), and then stained with $2 \mu \mathrm{g} / \mathrm{ml}$ DAPI. Slides were incubated in a moist box at $20{ }^{\circ} \mathrm{C}$ in the dark for $25 \mathrm{~min}$. After staining, preparations were briefly washed, and slides were mounted in McIlvaine buffer $\mathrm{pH} 7$ and sealed with rubber solution.

\section{Karyotype analysis}

For the chromosome characterization, the measurement on the microphotographs of the DAPI stained chromosome preparations were performed by means of MicroMeasure sofware 
Table 1 - Passiflora species of the Institute of Floriculture collection, voucher numbers and collection sites.

\begin{tabular}{|c|c|c|c|}
\hline Subgenus & Species & Code & Site of colection \\
\hline Passiflora & Passiflora alata Curtis & 20041119A1 & Donation \\
\hline Passiflora & Passiflora alata Curtis & 20050814B1 & San Justo, Buenos Aires \\
\hline Passiflora & Passiflora alata Curtis & 20100131A1 & Puerto Madero, Ciudad de Buenos Aires \\
\hline Passiflora & Passiflora alata Curtis & 20140606A1 & Famaillá, Tucumán \\
\hline Passiflora & Passiflora amethystina JC Mikan & 20050707A7 & Donation \\
\hline Passiflora & Passiflora caerulea L. & 20050318A1 & Guayquiraró, Corrientes \\
\hline Passiflora & Passiflora caerulea L. & $20051202 \mathrm{C} 1$ & Cerro Azul, Misiones \\
\hline Passiflora & Passiflora caerulea L. & $20051202 \mathrm{G} 1$ & Cerro Corá, Misiones \\
\hline Passiflora & Passiflora caerulea L. & 20071124A1 & Chañar Ladeado, Santa Fe \\
\hline Passiflora & Passiflora caerulea L. & 20071124A2 & Chañar Ladeado, Santa Fe \\
\hline Passiflora & Passiflora caerulea L. & 20071124A4 & Chañar Ladeado, Santa Fe \\
\hline Passiflora & Passiflora caerulea L. & 20071124A9 & Chañar Ladeado, Santa Fe \\
\hline Passiflora & Passiflora caerulea L. & 20071124A8 & Chañar Ladeado, Santa Fe \\
\hline Passiflora & Passiflora caerulea L. & $20091012 J 4$ & San Martín, Corrientes \\
\hline Passiflora & Passiflora caerulea L. & $05-101$ & Valle de Lerma, Salta \\
\hline Passiflora & Passiflora caerulea L. & $05-102$ & Salta capital, Salta \\
\hline Passiflora & Passiflora caerulea L. & $05-43$ & Castelar, Buenos Aires \\
\hline Passiflora & Passiflora caerulea L. & 20050608A2 & INTA Castelar, Buenos Aires \\
\hline Passiflora & Passiflora caerulea L. & 20050608A1 & INTA Castelar, Buenos Aires \\
\hline Passiflora & Passiflora capsularis L. & $20081101 \mathrm{~A} 2$ & San Pedro, Misiones \\
\hline Passiflora & Passiflora cincinnata Mast. & $05-46 \# 1$ & Donation \\
\hline Passiflora & Passiflora cincinnata Mast. & $05-46 \# 2$ & Donation \\
\hline Passiflora & Passiflora edulis f. flavicarpa O. Deg. & 20050707A3 & Donation \\
\hline Passiflora & Passiflora edulis f. flavicarpa O. Deg. & $12-169$ & Donation \\
\hline Passiflora & Passiflora edulis f. flavicarpa O. Deg. & $12-170$ & Donation \\
\hline Passiflora & Passiflora edulis $f$. flavicarpa O. Deg. & $07-247$ & Donation \\
\hline Passiflora & Passiflora edulis $f$. flavicarpa $\mathrm{O}$. Deg. & $12-357$ & Donation \\
\hline Passiflora & Passiflora edulis $f$. flavicarpa $\mathrm{O}$. Deg. & $12-391$ & Donation \\
\hline Passiflora & Passiflora elegans Mast. & $06-618$ & Santo Tomé, Corrientes \\
\hline Passiflora & Passiflora elegans Mast. & $06-619 \# 1$ & Santo Tomé, Corrientes \\
\hline Passiflora & Passiflora elegans Mast. & $06-619 \# 2$ & Santo Tomé, Corrientes \\
\hline Passiflora & Passiflora elegans Mast. & $06-619 \# 3$ & Santo Tomé, Corrientes \\
\hline Passiflora & Passiflora elegans Mast. & $10-461$ & IF-INTA (06-619\#3 open pollination) \\
\hline Dysosmia & Passiflora foetida L. & 20070126A6 & Matacos, Formosa \\
\hline Dysosmia & Passiflora foetida $\mathrm{L}$. & 20070126B4 & Bermejo, Formosa \\
\hline Decaloba & Passiflora misera Kunth. & $06-83$ & Federación, Entre Ríos \\
\hline Decaloba & Passiflora misera Kunth. & 20061129B1 & Santo Tomé, Corrientes \\
\hline Decaloba & Passiflora misera Kunth. & 20061129E2 & Santo Tomé, Corrientes \\
\hline
\end{tabular}




\begin{tabular}{llll}
\hline Subgenus & Species & Code & Site of colection \\
\hline Passiflora & Passiflora mooreana Hook. & 20061201A1 & Mercedes, Corrientes \\
Passiflora & Passiflora mooreana Hook. & $20070125 \mathrm{~B} 1$ & Matacos, Formosa \\
Decaloba & Passiflora morifolia Mast. & $20080411 \mathrm{E} 1$ & Ledesma, Jujuy \\
Decaloba & Passiflora suberosa L. & $06-477 \# 1$ & IF-INTA \\
Decaloba & Passiflora suberosa L. & $06-477 \# 2$ & IF-INTA \\
Decaloba & Passiflora suberosa L. & $20050707 \mathrm{~A} 4$ & Donation \\
Decaloba & Passiflora suberosa L. & 20091209C1 & San Javier, Santa Fe \\
Passiflora & Passiflora tenuifila Killip & $20140423 \mathrm{H} 1$ & Donation \\
Passiflora & Passiflora tucumanensis Hook. & $20090922 \mathrm{~A} 1$ & Pucará, Jujuy \\
Passiflora & Passiflora tucumanensis Hook. & 20110203B1 & Belén, Catamarca \\
Passiflora & Passiflora tucumanensis Hook. & 20110204A1 & Andalgalá, Catamarca \\
\hline
\end{tabular}

version 3.3 (<www.colostate.edu/Depts/Biology/ MicroMeasure $>$ ). The haploid chromosome length (HCL) for each studied species was calculated as the mean length of the chromosomes in a cell of at least five cells and then was divided by the ploidy level. The nomenclature used for chromosome morphology is that of Levan et al. (1964). For the analyses, we used two intrachromosomal asymmetry indices: $\mathrm{A}_{1}$ [A1 = 1-(short arm/long arm)/n] (Romero Zarco 1986) and MCA [MCA = (long arm - short arm) $/($ long arm + short arm)*100] (Peruzzi \& Eroğlu 2013). Also, two coefficients of variation were studied: $\mathrm{CV}$ of centromeric index (CVci) $[\mathrm{CVci}=$ standard deviation of the centromeric index/mean centromeric index $x$ 100] and $\mathrm{CV}$ of the chromosome length $(\mathrm{CVcl})[\mathrm{CVcl}=$ standard deviation of the chromosome length/mean chromosome length $\mathrm{x}$ 100] (Paszco 2006). Mean values of the karyotypes were calculated from measurements of a minimum of five scattered metaphase plates in each accession. The idiograms for each species were constructed using Microsoft Power Point 2016. The relationships between HCL and asymmetry indices were analyzed by means of linear regressions and ANOVA tests with BSS comparisons.

\section{FISH DNA probes}

For FISH analysis, rDNA $5 \mathrm{~S}$ and $18 \mathrm{~S}$ sequences were isolated and amplified from total genomic DNA of $P$. edulis $f$. flavicarpa by polymerase chain reaction (PCR). The $5 \mathrm{~s}$ primer sequences were designed according to Coelho et al. (2016)

$$
\text { S: 3' GTGCGATCATACCAGCAGCTTAA }
$$
TGCACCGG 5'-

\section{A: 5' GAGGTGCAACACGAGGACTTCC} CAGGAGG 3'.

The $18 \mathrm{~S}$ primers were designed according to the maize sequence of 18S rDNA (Realini 2017), S: 3' GAACCTACACCATCGGCAAA 5'- A: 5' TCATTACTCCGATCCCGAAG 3'.

The probes were biotin and digoxigeninlabelled by PCR, using fluorescently conjugated nucleotide 16-biotin dUTP (Sigma) and 11-digoxigenin-dUTP (Roche).

\section{GISH DNA probes}

To test the genomic affinity among the plants in the collection GISH assays were performed among species of the three subgenera available for breeding of genus Passiflora. To improve resolution of GISH technique, genomic DNA probe from species with the smaller chromosomes (subgenus Decaloba and Dysosmia) were hybridized on mitotic preparations of species with larger chromosomes (subgenus Passiflora). For the GISH trials, P. suberosa was selected for having an intermediate amount of DNA for the group according to Sader et al. (2019). To represent subgenus Dysosmia, DNA of the only available species of that group in the collection, $P$. foetida, was used as probe. These probes were tested on mitotic preparations of $P$. amethystina, $P$. caerulea and $P$. edulis which have a mean DNA size for subgenus Passiflora. Total genomic DNA from young leaves from species was isolated using a Wizard Genomic DNA Purification kit (Promega) and biotin labelled using the BioNick DNA Labeling System, (Thermo Fisher Scientific) according to manufacturer instructions. 
In situ hybridization

For the in situ hybridization procedure, slide preparations were incubated in $100 \mu \mathrm{g} \mathrm{mL}-1$ of RNAse in $2 \times$ saline sodium citrate $(2 \times \mathrm{SSC})$ for $1 \mathrm{~h}$ at $37^{\circ} \mathrm{C}$ and washed in $2 \times \mathrm{SSC}$ at room temperature. The slides were post-fixed in $4 \%(\mathrm{w} / \mathrm{v})$ paraformaldehyde for $10 \mathrm{~min}$ and washed in $2 \times$ SSC. The preparations were dehydrated in a graded ethanol series and air-dried. For FISH assays, each slide was subjected to $30 \mu \mathrm{L}$ of the hybridization mixture ( $15 \mu$ l of formamide, $6 \mu l$ of dextran sulfate, $3 \mu \mathrm{l}$ of 2 XSSC buffer, Sodium Dodecyl Sulfate-SDS $10 \%$ and $1 \mathrm{ul}$ of salmon sperm DNA) with $50 \mathrm{ng}$ of each labelled probe.

For GISH experiments, $45 \mathrm{ng}$ of labeled genomic DNA (probe) and 450 ng of blocking DNA were dissolving them together in hybridization mixture according to Melo et al. (2015).

The hybridization mixtures were denatured for $15 \mathrm{~min}$ at $75{ }^{\circ} \mathrm{C}$. The slides were placed on a thermocycler at $75{ }^{\circ} \mathrm{C}$ for $7 \mathrm{~min}, 45^{\circ} \mathrm{C}$ for $10 \mathrm{~min}$ and $38^{\circ} \mathrm{C}$ for $10 \mathrm{~min}$, and then incubated overnight at $37^{\circ} \mathrm{C}$. Following hybridization, the slides were incubated in the detection buffer containing a solution of $2.5 \%$ bovine serum albumin and the corresponding detection antibody $\mathrm{Cy} 3$ conjugate or antidigoxigenin- fluorescein isothiocyanate (FITC) for $1 \mathrm{~h}$ at $37^{\circ} \mathrm{C}$ and washed in $4 \times \mathrm{SSC} /$ Tween buffer. Slides were counterstained with $1 \mu \mathrm{g} \mathrm{mL}-1$ of DAPI in $4 \times \mathrm{SSC} /$ Tween buffer for $40 \mathrm{~min}$ at room temperature and then mounted in VectaShield solution (Vector Lab). Slides were examined with a Carl Zeiss Axiophot epifluorescence microscope with appropriate Carl Zeiss filters coupled with a Leica DC 250 digital camera and with an image analyzer Leica IM 1000. The location of hybridization signals were based on the observation of at least 5 complete metaphases for each analyzed species.

\section{Results}

Karyotypes and idiograms

Chromosomal counts were performed for 49 genotypes corresponding to 14 Argentinean Passiflora species (Tab. 1). The mitotic chromosomes morphology, rDNA chromosome position and representative idiograms for each species of Passiflora are presented in Figures 1 and 2. All the studied species showed intra-karyotypic variation in the chromosome length (Tab. 2).

Chromosome counts in subgenus Decaloba species were $2 \mathrm{n}=12$ for $P$. capsularis, $P$. misera and P. morifolia, and $2 \mathrm{n}=24$ in P. suberosa. In the species of subgenus Passiflora, the somatic numbers were $2 \mathrm{n}=18$ for $P$. alata, $P$. amethystina, $P$. caerulea, P. cincinnata, $P$. edulis, $P$. elegans, $P$. tenuifila and $P$. tucumanensis, $2 \mathrm{n}=18$ and $2 \mathrm{n}=36$ for $P$. mooreana, while $P$. foetida from subgenus Dysosmia presented $2 \mathrm{n}=20$ (Fig. 1).

The joint analysis of the species of genus Passiflora showed a range of chromosome sizes (Fig. 2), from a maximum values of $8.9 \pm 1.1 \mu \mathrm{m}$ (chromosome 1 of $P$. alata) to a minimum value of $1.0 \pm 0.2 \mu \mathrm{m}$ (chromosome 10 of $P$. foetida) (Tab. 2). The haploid chromosome length (HCL) values ranged from $57.95 \pm 3.68 \mu \mathrm{m}$ in P. alata to $10.61 \pm$ $1.24 \mu \mathrm{m}$ in P. capsularis (Tab. 3).

In subgenus Passiflora, all of the studied species exhibited diploid levels, with somatic numbers $2 \mathrm{n}=2 \mathrm{x}=18$ while in $P$. mooreana, diploid and tetraploid individuals $(2 \mathrm{n}=4 \mathrm{x}=36)$ were detected. Total haploid chromosome lengths (HCL) in this subgenus varies between $57.95 \pm 3.68 \mu \mathrm{m}$ and $25.32 \pm 3.10 \mu \mathrm{m}$, in P. alata and P. tucumanensis, respectively. All chromosomes were metacentric, except for submetacentric chromosome 1 of $P$. mooreana and chromosome 6 of $P$. amethystine (Fig. 2). The mean values of intrachromosomal asymmetry indexes A1 calculated for the subgenus were between $0.30 \pm 0.04$ for $P$. mooreana, and 0.19 \pm 0.03 for $P$. caerulea. Likewise, the mean values of the centromeric asymmetry indexes $\mathrm{M}_{\mathrm{CA}}$, were between $0.19 \pm 0.03$ and $0.11 \pm 0.02$, respectively. The coefficient of variation of chromosome length CVcl was between 13.77 in P. caerulea to 20.44 in $P$. alata, while the coefficient of variation of centromeric index CVci was between 3.88 in $P$. tucumanensis and 6.64 in P. mooreana (Tab. 3).

In species of the subgenus Decaloba, haploid genome length ranged from $17.67 \pm 3.09 \mu \mathrm{m}$ for $P$. morifolia to $10.61 \pm 1.24 \mu \mathrm{m}$ for $P$. capsularis. In this subgenus, the mean values of A1 indexes were between $0.39 \pm 0.05$ for $P$. suberosa and $0.32 \pm 0.07$ for P. morifolia. $\mathrm{M}_{\mathrm{CA}}$ indexes ranged from $0.27 \pm$ 0.04 for $P$. suberosa, and $0.20 \pm 0.04$ for $P$. capsularis and $P$. morifolia. For subgenus Decaloba, values of $\mathrm{CVcl}$ were between 25.48 and 40.58 while those of CVci were between 12.80 and 5.78 (Tab. 3).

The only studied species of the subgenus Dysosmia, P. foetida $(2 \mathrm{n}=2 \mathrm{x}=20)$ showed a length of the basic chromosomal complement of $14.71 \pm$ $3.08 \mu \mathrm{m}$. All chromosomes were metacentric except for the submetacentric chromosome 4. A1 index was $0.29 \pm 0.04$, MCA was $0.18 \pm 0.03, \mathrm{CV}$ cl was 26.03 and CVci 6.75 (Tab. 3). 


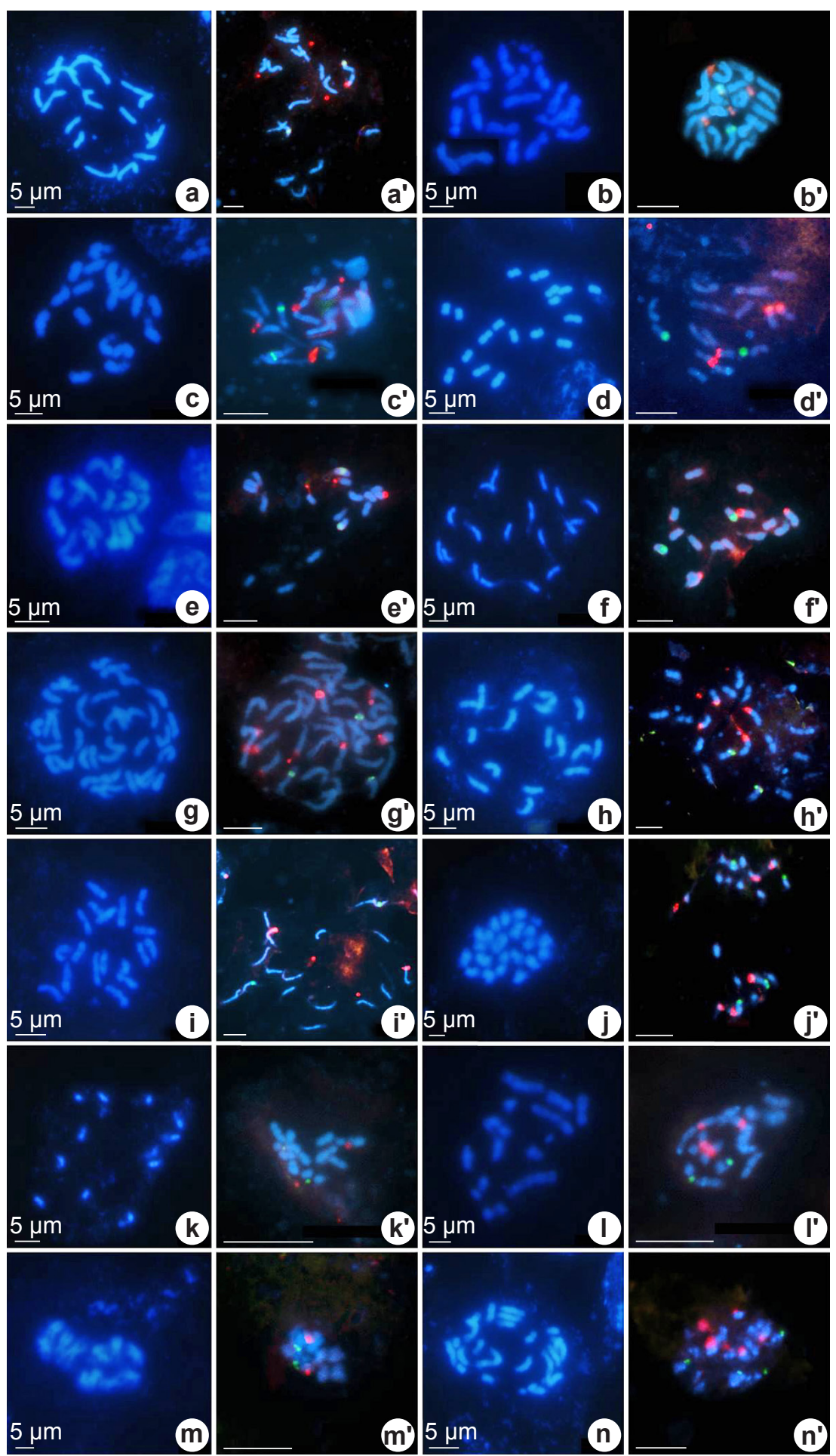

Figure 1 - a-n. Mitotic chromosomes of species of Passiflora. Dapi counterstain (blue), 18s sites biotin-Cy3 labelled (red) and 5s sites digoxigenin-antidigoxigenin-FITC labelled (green) - a. P. alata, b. P. amethystina, c. P. caerulea, d. $P$. cincinnata, e. $P$. edulis $f$. flavicarpa and f. $P$. elegans with $2 \mathrm{n}=2 \mathrm{x}=18$; g. $P$. mooreana with $2 \mathrm{n}=4 \mathrm{x}=36$; $\mathrm{h}$. $P$. tenuifila, i. $P$. tucumanensis with $2 \mathrm{n}=2 \mathrm{x}=18 ; \mathrm{j} . P$. foetida $2 \mathrm{n}=2 \mathrm{x}=20 ; \mathrm{k}$. $P$. capsularis, $1 . P$. misera and $\mathrm{m} . P$. morifolia with $2 \mathrm{n}=2 \mathrm{x}=12 ; \mathrm{n}$. P. suberosa with $2 \mathrm{n}=4 \mathrm{x}=24$. Letters without apostrophe indicates DAPI stain, with apostrophe indicates FISH. Scale bars: $\mu \mathrm{m}$. 


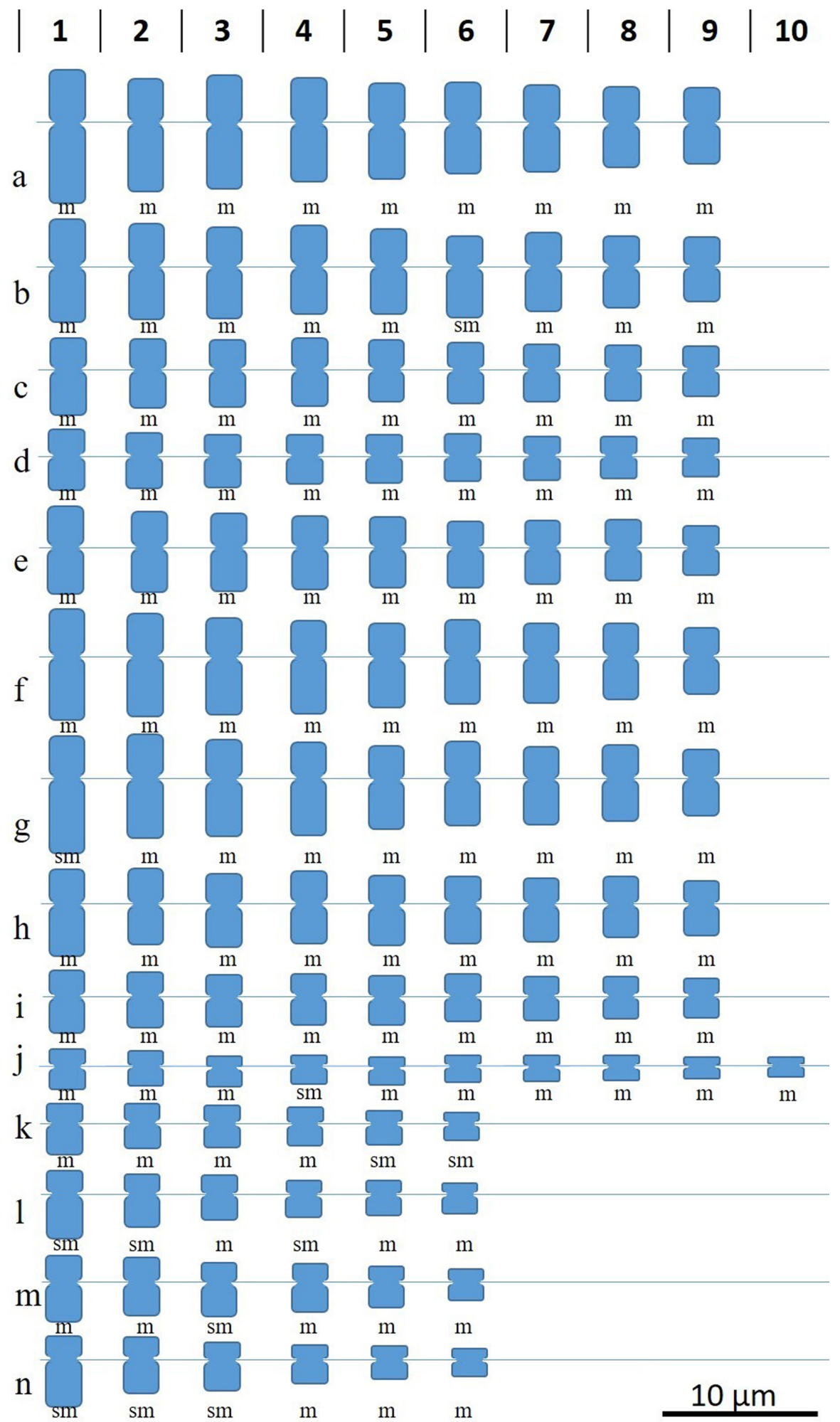

Figure 2 - a-n. Karyotypes and centromeric position of species of Passiflora - a. P. alata; b. P. amethystina, c. P. caerulea, d. $P$. cincinnata, e. $P$. edulis f. flavicarpa and f. $P$. elegans with $2 \mathrm{n}=2 \mathrm{x}=18$; g. $P$. mooreana with $2 \mathrm{n}=$ $4 \mathrm{x}=36$; h. $P$. tenuifila, i. $P$. tucumanensis with $2 \mathrm{n}=2 \mathrm{x}=18 ;$ j. $P$. foetida $2 \mathrm{n}=2 \mathrm{x}=20 ;$ k. P. capsularis, 1 . P. misera and $\mathrm{m}$. $P$. morifolia with $2 \mathrm{n}=2 \mathrm{x}=12 ; \mathrm{n}$. $P$. suberosa with $2 \mathrm{n}=4 \mathrm{x}=24$. Scale bar: $10 \mu \mathrm{m}$. 
Table 2 - Morphometric characteristics of the chromosomes of species of Passiflora. Mean measurements and standard deviation of $\mathrm{CL}=$ Chromosome length $(\mu \mathrm{m})$. Different letter indicates significative differences among the length of the chromosomes of the set $(\mathrm{p}=<0.05)$. $\mathrm{L}=$ long $\operatorname{arm}(\mu \mathrm{m}) ; \mathrm{S}=\operatorname{short} \operatorname{arm}(\mu \mathrm{m}) ; \mathrm{CI}=$ centromeric index $(\%)$.

\begin{tabular}{|c|c|c|c|c|c|c|c|c|c|c|c|}
\hline \multicolumn{2}{|c|}{ Chromosome } & \multirow{2}{*}{$\frac{1}{8.9 \pm 1.1^{\mathrm{a}}}$} & \multirow{2}{*}{$\frac{2}{7.7 \pm 0.9^{\mathrm{b}}}$} & \multirow{2}{*}{$\frac{\mathbf{3}}{7.2 \pm 0.7^{\mathrm{b}}}$} & \multirow{2}{*}{$\frac{4}{6.8 \pm 0.4^{\mathrm{c}}}$} & \multirow{2}{*}{$\frac{5}{6.4 \pm 0.4^{\mathrm{c}}}$} & \multirow{2}{*}{$\frac{\mathbf{6}}{5.9 \pm 0.4^{\mathrm{d}}}$} & \multirow{2}{*}{$\frac{7}{5.7 \pm 0.3^{\mathrm{d}}}$} & \multirow{2}{*}{$\frac{\mathbf{8}}{5.0 \pm 0.3^{\mathrm{e}}}$} & \multirow{2}{*}{$\frac{9}{4.4 \pm 0.2^{\mathrm{f}}}$} & \multirow{2}{*}{$\begin{array}{l}10 \\
-\end{array}$} \\
\hline & $\mathrm{CL}$ & & & & & & & & & & \\
\hline \multirow{3}{*}{ 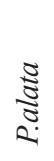 } & $\mathrm{L}$ & $5.1 \pm 0.9$ & $4.3 \pm 0.9$ & $4.1 \pm 0.4$ & $3.7 \pm 0.5$ & $3.4 \pm 0.5$ & $3.1 \pm 0.6$ & $3.0 \pm 0.4$ & $2.7 \pm 0.3$ & $2.5 \pm 0.2$ & - \\
\hline & S & $3.3 \pm 0.8$ & $3.2 \pm 0.9$ & $3.0 \pm 0.9$ & $2.7 \pm 0.7$ & $2.6 \pm 0.4$ & $2.5 \pm 0.3$ & $2.3 \pm 0.4$ & $2.2 \pm 0.2$ & $2.2 \pm 0.3$ & - \\
\hline & $\mathrm{CI}$ & 39.8 & 42.9 & 42.7 & 42.7 & 41.9 & 43.9 & 44.2 & 45.3 & 46.5 & - \\
\hline \multirow{5}{*}{ 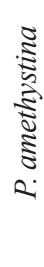 } & CL & $7.2 \pm 0.8^{\mathrm{a}}$ & $6.4 \pm 0.5^{\mathrm{b}}$ & $6.1 \pm 0.5^{\mathrm{b}}$ & $5.8 \pm 0.5^{\mathrm{c}}$ & $5.5 \pm 0.5^{\mathrm{c}}$ & $5.2 \pm 0.6^{\mathrm{d}}$ & $5.0 \pm 0.6^{\mathrm{d}}$ & $4.6 \pm 0.6^{\mathrm{e}}$ & $4.2 \pm 0.6^{\mathrm{e}}$ & - \\
\hline & L & $3.5 \pm 0.6$ & $3.4 \pm 0.6$ & $3.3 \pm 0.2$ & $3.0 \pm 0.3$ & $3.0 \pm 0.4$ & $3.2 \pm 0.4$ & $2.8 \pm 0.4$ & $2.6 \pm 0.1$ & $2.2 \pm 0.2$ & - \\
\hline & $\mathrm{S}$ & $3.0 \pm 0.5$ & $2.7 \pm 0.2$ & $2.4 \pm 0.5$ & $2.5 \pm 0.3$ & $2.3 \pm 0.4$ & $1.9 \pm 0.2$ & $2.0 \pm 0.2$ & $1.8 \pm 0.3$ & $1.8 \pm 0.3$ & - \\
\hline & CI & 45.6 & 44.2 & 41.8 & 45.8 & 42.7 & 36.9 & 42.0 & 41.8 & 45.2 & - \\
\hline & CL & $4.9 \pm 0.9^{\mathrm{a}}$ & $4.4 \pm 0.7^{\mathrm{b}}$ & $4.2 \pm 0.7^{b}$ & $4.0 \pm 0.6^{\mathrm{b}}$ & $3.9 \pm 0.5^{\mathrm{b}}$ & $3.8 \pm 0.6^{c}$ & $3.6 \pm 0.5^{\mathrm{c}}$ & $3.4 \pm 0.5^{\mathrm{c}}$ & $3.1 \pm 0.5^{\mathrm{c}}$ & - \\
\hline \multirow{3}{*}{ 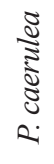 } & $\mathrm{L}$ & $2.9 \pm 0.8$ & $2.4 \pm 0.5$ & $2.4 \pm 0.4$ & $2.3 \pm 0.3$ & $2.0 \pm 0.3$ & $2.1 \pm 0.3$ & $2.0 \pm 0.3$ & $1.9 \pm 0.4$ & $1.6 \pm 0.3$ & - \\
\hline & S & $2.0 \pm 0.4$ & $1.9 \pm 0.3$ & $1.8 \pm 0.3$ & $1.8 \pm 0.3$ & $1.8 \pm 0.3$ & $1.7 \pm 0.3$ & $1.5 \pm 0.2$ & $1.5 \pm 0.2$ & $1.4 \pm 0.2$ & - \\
\hline & $\mathrm{CI}$ & 40.4 & 44.1 & 43.6 & 48.8 & 47.6 & 44.1 & 42.8 & 43.2 & 46.2 & - \\
\hline \multirow{4}{*}{ 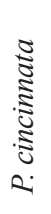 } & CL & $4.2 \pm 0.9^{\mathrm{a}}$ & $3.8 \pm 0.7^{\mathrm{a}}$ & $3.5 \pm 0.8^{\mathrm{b}}$ & $3.3 \pm 0.7^{\mathrm{b}}$ & $3.1 \pm 0.7^{\mathrm{b}}$ & $3.0 \pm 0.6^{\mathrm{b}}$ & $2.8 \pm 0.5^{\mathrm{c}}$ & $2.6 \pm 0.3^{\mathrm{c}}$ & $2.4 \pm 0.3^{\mathrm{c}}$ & - \\
\hline & $\mathrm{L}$ & $2.2 \pm 0.2$ & $2.1 \pm 0.2$ & $2.0 \pm 0.2$ & $1.8 \pm 0.2$ & $1.7 \pm 0.2$ & $1.6 \pm 0.2$ & $1.5 \pm 0.2$ & $1.4 \pm 0.2$ & $1.3 \pm 0.1$ & - \\
\hline & $\mathrm{S}$ & $1.6 \pm 0.2$ & $1.4 \pm 0.2$ & $1.3 \pm 0.2$ & $1.2 \pm 0.2$ & $1.2 \pm 0,1$ & $1.3 \pm 0.1$ & $1.1 \pm 0.2$ & $1.1 \pm 0.1$ & $0.9 \pm 0.1$ & - \\
\hline & $\mathrm{CI}$ & 42.2 & 40.2 & 38.6 & 41.5 & 42.1 & 45.0 & 43.3 & 44.4 & 43.6 & - \\
\hline \multirow{5}{*}{ 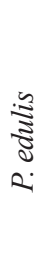 } & CL & $6.4 \pm 0.5^{\mathrm{a}}$ & $5.5 \pm 0.5^{\mathrm{b}}$ & $5.1 \pm 0.6^{c}$ & $5.0 \pm 0.6^{\mathrm{c}}$ & $4.7 \pm 0.7^{\mathrm{c}}$ & $4.5 \pm 0.7^{\mathrm{c}}$ & $4.2 \pm 0.6^{\mathrm{d}}$ & $3.9 \pm 0.5^{\mathrm{d}}$ & $3.4 \pm 0.5^{\mathrm{e}}$ & - \\
\hline & $\mathrm{L}$ & $3.0 \pm 0.4$ & $2.8 \pm 0.4$ & $2.8 \pm 0.4$ & $2.7 \pm 0.6$ & $2.5 \pm 0.4$ & $2.6 \pm 0.6$ & $2.3 \pm 0.5$ & $2.0 \pm 0.3$ & $1.7 \pm 0.4$ & - \\
\hline & $\mathrm{S}$ & $2.6 \pm 0.4$ & $2.2 \pm 0.3$ & $2.1 \pm 0.4$ & $2.0 \pm 0.3$ & $1.9 \pm 0.3$ & $1.6 \pm 0.1$ & $1.6 \pm 0.2$ & $1.7 \pm 0.2$ & $1.3 \pm 0.5$ & - \\
\hline & CI & 46.8 & 44.1 & 43.3 & 42.1 & 42.7 & 39.0 & 41.7 & 45.4 & 43.4 & - \\
\hline & CL & $4.3 \pm 0.6^{\mathrm{a}}$ & $3.9 \pm 0.4^{\mathrm{b}}$ & $3.7 \pm 0.3^{\mathrm{c}}$ & $3.5 \pm 0.3^{\mathrm{c}}$ & $3.3 \pm 0.3^{\mathrm{d}}$ & $3.2 \pm 0.3^{\mathrm{d}}$ & $3.1 \pm 0.3^{\mathrm{e}}$ & $2.9 \pm 0.2^{\mathrm{e}}$ & $2.7 \pm 0.3^{\mathrm{f}}$ & - \\
\hline \multirow{3}{*}{$\begin{array}{l}\tilde{5} \\
8 \\
\frac{3}{0} \\
2\end{array}$} & $\mathrm{~L}$ & $2.5 \pm 0.3$ & $2.4 \pm 0.3$ & $2.1 \pm 0.2$ & $2.0 \pm 0.4$ & $2.0 \pm 0.2$ & $1.8 \pm 0.2$ & $1.8 \pm 0.2$ & $1.6 \pm 0.3$ & $1.5 \pm 0.2$ & - \\
\hline & $\mathrm{S}$ & $1.7 \pm 0.4$ & $1.5 \pm 0.3$ & $1.5 \pm 0.2$ & $1.4 \pm 0.2$ & $1.3 \pm 0.3$ & $1.3 \pm 0.3$ & $1.3 \pm 0.2$ & $1.3 \pm 0.2$ & $1.2 \pm 0.1$ & - \\
\hline & CI & 39.8 & 38.8 & 42.3 & 41.7 & 38.4 & 41.9 & 42.2 & 44.3 & 43.4 & - \\
\hline \multirow{5}{*}{ 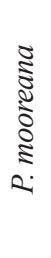 } & CL & $6.2 \pm 0.9^{\mathrm{a}}$ & $5.7 \pm 0.9^{\mathrm{b}}$ & $5.3 \pm 0.9^{b}$ & $5.0 \pm 0.8^{b}$ & $4.7 \pm 0.9^{\mathrm{c}}$ & $4.5 \pm 0.9^{\mathrm{c}}$ & $4.3 \pm 0.9^{c}$ & $4.1 \pm 0.9^{c}$ & $3.7 \pm 0.9^{\mathrm{d}}$ & - \\
\hline & $\mathrm{L}$ & $4.6 \pm 1.5$ & $3.7 \pm 0.7$ & $3.5 \pm 0.7$ & $3.5 \pm 0.9$ & $2.9 \pm 0.7$ & $2.9 \pm 0.7$ & $2.8 \pm 0.8$ & $2.6 \pm 0.6$ & $2.2 \pm 0.6$ & - \\
\hline & $\mathrm{S}$ & $2.5 \pm 0.8$ & $2.6 \pm 0.7$ & $2.4 \pm 0.5$ & $2.1 \pm 0.6$ & $2.1 \pm 0.4$ & $2.2 \pm 0.4$ & $1.9 \pm 0.5$ & $1.9 \pm 0.5$ & $1.6 \pm 0.4$ & - \\
\hline & $\mathrm{CI}$ & 35.3 & 41.0 & 40.1 & 38.4 & 39.9 & 44.0 & 41.1 & 43.7 & 42.4 & - \\
\hline & CL & $4.9 \pm 1.1^{\mathrm{a}}$ & $4.5 \pm 0.9^{\mathrm{b}}$ & $4.3 \pm 0.8^{\mathrm{b}}$ & $4.0 \pm 0.7^{\mathrm{c}}$ & $3.9 \pm 0.7^{c}$ & $3.7 \pm 0.6^{c}$ & $3.6 \pm 0.6^{\mathrm{c}}$ & $3.3 \pm 0.6^{\mathrm{d}}$ & $3.1 \pm 0.6^{\mathrm{d}}$ & - \\
\hline \multirow{7}{*}{ 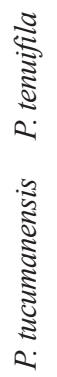 } & $\mathrm{L}$ & $3.1 \pm 0.8$ & $2.4 \pm 0 . .3$ & $2.5 \pm 0.4$ & $2.3 \pm 0.4$ & $2.3 \pm 0.5$ & $2.4 \pm 0.5$ & $2.2 \pm 0.5$ & $1.9 \pm 0.2$ & $1.8 \pm 0.2$ & - \\
\hline & $\mathrm{S}$ & $2.1 \pm 0.5$ & $2.1 \pm 0.4$ & $1.9 \pm 0.5$ & $1.9 \pm 0.3$ & $1.8 \pm 0.3$ & $1.6 \pm 0.3$ & $1.5 \pm 0.3$ & $1.6 \pm 0.2$ & $1.3 \pm 0.3$ & - \\
\hline & CI & 40.0 & 46.4 & 42.6 & 45.2 & 43.1 & 39.6 & 41.0 & 44.5 & 41.8 & - \\
\hline & CL & $3.6 \pm 0.6^{\mathrm{a}}$ & $3.2 \pm 0.4^{\mathrm{b}}$ & $3.0 \pm 0.4^{\mathrm{c}}$ & $2.9 \pm 0.3^{\mathrm{c}}$ & $2.8 \pm 0.3^{\mathrm{d}}$ & $2.7 \pm 0.3^{\mathrm{d}}$ & $2.5 \pm 0.3^{\mathrm{e}}$ & $2.4 \pm 0.4^{\mathrm{e}}$ & $2.2 \pm 0.4^{\mathrm{f}}$ & - \\
\hline & L & $2.2 \pm 0.5$ & $1.9 \pm 0.3$ & $1.7 \pm 0.2$ & $1.7 \pm 0.3$ & $1.6 \pm 0.2$ & $1.5 \pm 0.2$ & $1.4 \pm 0.1$ & $1.3 \pm 0.1$ & $1.2 \pm 0.2$ & - \\
\hline & S & $1.5 \pm 0.2$ & $1.3 \pm 0.2$ & $1.2 \pm 0.2$ & $1.2 \pm 0.2$ & $1.2 \pm 0.2$ & $1.2 \pm 0.2$ & $1.1 \pm 0.2$ & $1.1 \pm 0.2$ & $0.9 \pm 0.2$ & - \\
\hline & CI & 40.8 & 40.7 & 42.0 & 42.3 & 43.8 & 44.4 & 44.8 & 45.0 & 44.0 & - \\
\hline
\end{tabular}




\begin{tabular}{|c|c|c|c|c|c|c|c|c|c|c|c|}
\hline \multicolumn{2}{|c|}{ Chromosome } & \multirow{2}{*}{$\frac{1}{2.3 \pm 0.6^{\mathrm{a}}}$} & \multirow{2}{*}{$\frac{2}{2.0 \pm 0.5^{\mathrm{a}}}$} & \multirow{2}{*}{$\frac{\mathbf{3}}{1.6 \pm 0.3^{\mathrm{b}}}$} & \multirow{2}{*}{$\frac{\mathbf{4}}{1.5 \pm 0.3^{\mathrm{b}}}$} & \multirow{2}{*}{$\frac{5}{1.4 \pm 0.3^{\mathrm{b}}}$} & \multirow{2}{*}{$\frac{6}{1.3 \pm 0.2^{\mathrm{b}}}$} & \multirow{2}{*}{$\frac{7}{1.2 \pm 0.2^{\mathrm{c}}}$} & \multirow{2}{*}{$\frac{\mathbf{8}}{1.2 \pm 0.2^{\mathrm{c}}}$} & \multirow{2}{*}{$\frac{9}{1.1 \pm 0.2^{\mathrm{c}}}$} & \multirow{2}{*}{$\frac{10}{1.0 \pm 0.2^{\circ}}$} \\
\hline & HCL & & & & & & & & & & \\
\hline \multirow{3}{*}{ 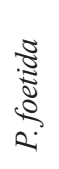 } & $\mathrm{L}$ & $1.2 \pm 0.3$ & $1.1 \pm 0.3$ & $1.1 \pm 0.25$ & $1.0 \pm 0.3$ & $0.9 \pm 0.2$ & $0.8 \pm 0.2$ & $0.7 \pm 0.2$ & $0.7 \pm 0.1$ & $0.6 \pm 0.2$ & $0.6 \pm 0.1$ \\
\hline & S & $0.9 \pm 0.4$ & $0.9 \pm 0.2$ & $0.7 \pm 0.1$ & $0.5 \pm 0.2$ & $0.6 \pm 0.2$ & $0.6 \pm 0.2$ & $0.5 \pm 0.1$ & $0.5 \pm 0.1$ & $0.4 \pm 0.1$ & $0.4 \pm 0.1$ \\
\hline & $\mathrm{CI}$ & 43.1 & 44.7 & 38.0 & 35.0 & 39.5 & 41.5 & 42.4 & 40.9 & 41.0 & 42.1 \\
\hline \multirow{5}{*}{ 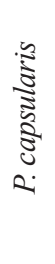 } & $\mathrm{HCL}$ & $2.4 \pm 0.3^{\mathrm{a}}$ & $2.0 \pm 0.2^{\mathrm{b}}$ & $1.8 \pm 0.2^{\mathrm{c}}$ & $1.7 \pm 0.2^{\mathrm{c}}$ & $1.5 \pm 0.2^{\mathrm{d}}$ & $1.3 \pm 0.2^{\mathrm{d}}$ & - & - & - & - \\
\hline & $\mathrm{L}$ & $1.8 \pm 0.4$ & $1.4 \pm 0.4$ & $1.3 \pm 0.3$ & $1.2 \pm 0.4$ & $1.1 \pm 0.2$ & $0.9 \pm 0.2$ & - & - & - & - \\
\hline & S & $1.1 \pm 0.4$ & $1.0 \pm 0.3$ & $1.0 \pm 0.3$ & $0.9 \pm 0.2$ & $0.7 \pm 0.2$ & $0.5 \pm 0.1$ & - & - & - & - \\
\hline & $\mathrm{CI}$ & 38.5 & 41.8 & 43.7 & 41.9 & 36.8 & 37.4 & - & - & - & - \\
\hline & $\mathrm{HCL}$ & $3.7 \pm 1.0^{\mathrm{a}}$ & $3.1 \pm 0.4^{\mathrm{b}}$ & $2.6 \pm 0.5^{b}$ & $2.5 \pm 0.6^{\mathrm{b}}$ & $2.1 \pm 0.7^{\mathrm{c}}$ & $1.7 \pm 0.7^{\mathrm{c}}$ & - & - & - & - \\
\hline \multirow{3}{*}{ 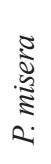 } & $\mathrm{L}$ & $2.7 \pm 1.3$ & $1.9 \pm 0.6$ & $1.5 \pm 0.3$ & $1.3 \pm 0.5$ & $1.1 \pm 0.3$ & $1.1 \pm 0.3$ & - & - & - & - \\
\hline & S & $1.3 \pm 0.3$ & $1.1 \pm 0.4$ & $1.1 \pm 0.2$ & $0.7 \pm 0.3$ & $0.7 \pm 0.2$ & $0.5 \pm 0.1$ & - & - & - & - \\
\hline & $\mathrm{CI}$ & 32.2 & 35.8 & 43.8 & 37.3 & 44.8 & 42.5 & - & - & - & - \\
\hline \multirow{4}{*}{ 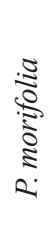 } & $\mathrm{HCL}$ & $3.2 \pm 0.7^{\mathrm{a}}$ & $2.6 \pm 0.6^{\mathrm{b}}$ & $2.3 \pm 0.5^{\mathrm{b}}$ & $2.1 \pm 0.4^{\mathrm{b}}$ & $1.8 \pm 0.4^{\mathrm{c}}$ & $1.5 \pm 0.4^{\mathrm{c}}$ & - & - & - & - \\
\hline & $\mathrm{L}$ & $2.4 \pm 0.5$ & $1.9 \pm 0.3$ & $2.0 \pm 0.6$ & $1.7 \pm 0.3$ & $1.4 \pm 0.2$ & $0.9 \pm 0.1$ & - & - & - & - \\
\hline & S & $1.5 \pm 0.4$ & $1.4 \pm 0.4$ & $1.1 \pm 0.1$ & $1.0 \pm 0.2$ & $0.9 \pm 0.1$ & $0.7 \pm 0.1$ & - & - & - & - \\
\hline & $\mathrm{CI}$ & 39.3 & 42.3 & 36.8 & 38.2 & 38.5 & 42.4 & - & - & - & - \\
\hline \multirow{4}{*}{ 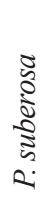 } & HCL & $4.5 \pm 1.0^{\mathrm{a}}$ & $3.6 \pm 0.5^{\mathrm{b}}$ & $3.0 \pm 0.4^{\mathrm{c}}$ & $2.5 \pm 0.3^{\mathrm{d}}$ & $2.1 \pm 0.3^{\mathrm{e}}$ & $1.6 \pm 0.3^{\mathrm{f}}$ & - & - & - & - \\
\hline & $\mathrm{L}$ & $2.9 \pm 0.3$ & $2.1 \pm 0.4$ & $1.8 \pm 0.3$ & $1.3 \pm 0.2$ & $1.1 \pm 0.1$ & $0.9 \pm 0.2$ & - & - & - & - \\
\hline & S & $1.3 \pm 0.5$ & $1.2 \pm 0.3$ & $1.0 \pm 0.3$ & $0.8 \pm 0.2$ & $0.7 \pm 0.1$ & $0.6 \pm 0.1$ & - & - & - & - \\
\hline & CI & 30.4 & 36.8 & 36.0 & 38.0 & 39.1 & 41.2 & - & - & - & - \\
\hline
\end{tabular}

The size of the basic chromosomal complement was larger in the species of the subgenus Passiflora than in the others. Comparison of haploid genome length shows that $P$. alata value is significantly larger than the rest of the studied species $(57.95 \mu \mathrm{m})$, followed by $P$. amethystina $(49.91 \mu \mathrm{m})$. No significant differences were found between the sizes of the chromosomal complements of the species $P$. mooreana, $P$. caerulea and $P$. edulis, neither between $P$. elegans, $P$. cincinnata and $P$. tucumanensis, as well as between the species of the subgenus Decaloba (P. misera, P. morifolia, $P$. suberosa and P. capsularis) and P. foetida (Tab. 3).

Close relationships were found between haploid chromosome length and asymmetry indices $\mathrm{A} 1\left(\mathrm{R}^{2}=0.65\right), \mathrm{CVcl}\left(\mathrm{R}^{2}=0.56\right)$ and MCA $\left(\mathrm{R}^{2}=0.50\right)$, while the regression was weaker with CVci $\left(\mathrm{R}^{2}=0.30\right)$ (Fig. 3).

\section{FISH rDNA sequences mapping}

Fluorescent in situ hybridization (FISH) assays on mitotic metaphases of native Passiflora species, using $5 \mathrm{~S}$ and $18 \mathrm{~S}$ sequences as probe showed variations in the number of hybridization signals among the species. Two $5 \mathrm{~S}$ hybridization signals were detected per somatic cell in species of subgenus Passiflora (P. alata, P. amethystina, $P$. caerulea, $P$. cincinnata, $P$. edulis $f$. flavicarpa, $P$. elegans, $P$. tucumanensis), and subgenus Decaloba ( $P$. capsularis, $P$. misera and $P$. morifolia) (Fig. 1). On the other hand, four $5 \mathrm{~S}$ hybridization signals were found in the tetraploids P. mooreana form subgenus Passiflora and P. suberosa from Decaloba, as well as in the diploid P. foetida from Dysosmia (Fig. 1g,j,n). Regarded to the $18 \mathrm{~S}$ hybridization signals, $P$. capsularis and P. morifolia from subgenus Decaloba presented two signals; while P. misera from the same subgenus and several species from subgenus Passiflora (P. alata, P. cincinnata and $P$. edulis $f$. flavicarpa) exhibited four. Passiflora amethystina, P. caerulea, P. elegans and $P$. tucumanensis showed six $18 \mathrm{~S}$ hybridization signals and $P$. suberosa (subgenus Decaloba) showed eight (Fig. 1). The tetraploid cytotype of P. mooreana (subgenus Passiflora) showed ten 18s signals (Fig. 1g'). 
Table 3 - Number of rDNA sites and asymmetry indexes in the karyotypes of Passiflora species. HCL = haploid length of the chromosome set; $\mathrm{CVcl}=$ coefficient of variation of chromosome length; $\mathrm{CVci}=$ coefficient of variation of centromeric index (Paszko 2006); A1 = intrachromosomal asymmetry index (Romero Zarco 1986); MCA = mean centromeric asymmetry (Peruzzi \& Eroğlu 2013); SD = standard deviation; * values of $1 \mathrm{C}$ genome size according to Sader et al. (2019). Different letters in HCL indicates statistical differences among species.

\begin{tabular}{|c|c|c|c|c|c|c|c|c|c|c|}
\hline & $\begin{array}{l}\text { Somatic } \\
\text { number }\end{array}$ & $\begin{array}{c}\text { Karyotype } \\
\text { formula }\end{array}$ & $\begin{array}{c}\mathbf{5 s} \\
\text { sites }\end{array}$ & $\begin{array}{l}18 s \\
\text { sites }\end{array}$ & $\begin{array}{c}\text { HCL } \\
(\mu \mathrm{m})-\mathrm{SD}\end{array}$ & CVcl & CVci & A1-SD & MCA-SD & $\begin{array}{c}1 \mathrm{C} \\
\text { genome } \\
\text { size * }\end{array}$ \\
\hline P. alata & $2 n=2 x=18$ & $9 \mathrm{~m}$ & 2 & 4 & $57.95 \pm 3.68^{\mathrm{a}}$ & 20.44 & 4.50 & $0.22 \pm 0.02$ & $0.13 \pm 0.01$ & 2.208 \\
\hline P. amethystina & $2 n=2 x=18$ & $9 \mathrm{~m}$ & 2 & 6 & $49.91 \pm 5.08^{b}$ & 14.79 & 6.48 & $0.24 \pm 0.05$ & $0.14 \pm 0.03$ & - \\
\hline P. caerulea & $2 n=2 x=18$ & $8 \mathrm{~m}+1 \mathrm{sm}$ & 2 & 6 & $40.96 \pm 10.29^{c}$ & 13.77 & 5.80 & $0.19 \pm 0.03$ & $0.11 \pm 0.02$ & 1.386 \\
\hline P. cincinnata & $2 n=2 x=18$ & $9 \mathrm{~m}$ & 2 & 4 & $28.82 \pm 5.99^{\mathrm{e}}$ & 17.10 & 4.81 & $0.26 \pm 0.02$ & $0.16 \pm 0.01$ & - \\
\hline P. edulis & $2 n=2 x=18$ & $9 \mathrm{~m}$ & 2 & 4 & $42.39 \pm 4.18^{c}$ & 17.97 & 5.18 & $0.22 \pm 0.04$ & $0.15 \pm 0.03$ & 1.258 \\
\hline P. elegans & $2 n=2 x=18$ & $9 \mathrm{~m}$ & 2 & 6 & $30.80 \pm 2.62^{\mathrm{e}}$ & 14.10 & 4.86 & $0.27 \pm 0.04$ & $0.17 \pm 0.03$ & - \\
\hline P. mooreana & $2 n=4 x=36$ & $8 \mathrm{~m}+1 \mathrm{sm}$ & 4 & 10 & $43.41 \pm 8.44^{\mathrm{c}}$ & 18.51 & 6.64 & $0.30 \pm 0.04$ & $0.19 \pm 0.03$ & - \\
\hline P. tenuifila & $2 \mathrm{n}=2 \mathrm{x}=18$ & $9 \mathrm{~m}$ & 2 & 6 & $35.23 \pm 6.39^{d}$ & 14.96 & 5.49 & $0.24 \pm 0.02$ & $0.15 \pm 0.01$ & - \\
\hline P. tucumanensis & $2 n=2 x=18$ & $9 \mathrm{~m}$ & 2 & 6 & $25.32 \pm 3.10^{\mathrm{e}}$ & 16.24 & 3.88 & $0.23 \pm 0.04$ & $0.14 \pm 0.03$ & - \\
\hline P. foetida & $2 n=2 x=20$ & $9 \mathrm{~m}+1 \mathrm{sm}$ & 4 & 6 & $14.71 \pm 3.08^{\mathrm{f}}$ & 26.03 & 6.75 & $0.29 \pm 0.04$ & $0.18 \pm 0.03$ & 0.481 \\
\hline P. capsularis & $2 n=2 x=12$ & $4 m+2 s m$ & 2 & 2 & $10.61 \pm 1.24^{\mathrm{f}}$ & 25.48 & 7.04 & $0.37 \pm 0.05$ & $0.20 \pm 0.04$ & 0.319 \\
\hline P. misera & $2 \mathrm{n}=2 \mathrm{x}=12$ & $3 m+3 s m$ & 2 & 4 & $15.70 \pm 3.25^{f}$ & 40.58 & 12.80 & $0.37 \pm 0.02$ & $0.26 \pm 0.03$ & 0.253 \\
\hline P. morifolia & $2 \mathrm{n}=2 \mathrm{x}=12$ & $5 \mathrm{~m}+1 \mathrm{sm}$ & 2 & 2 & $17.67 \pm 3.09^{f}$ & 27.69 & 5.78 & $0.32 \pm 0.07$ & $0.20 \pm 0.05$ & 0.505 \\
\hline P. suberosa & $2 n=4 x=24$ & $3 m+3 s m$ & 4 & 8 & $17.31 \pm 2.51^{\mathrm{f}}$ & 38.11 & 9.96 & $0.39 \pm 0.05$ & $0.27 \pm 0.04$ & 0.684 \\
\hline
\end{tabular}

Genomic affinity among subgenera In situ genomic hybridizations were performed on the mitotic chromosomes of species from subgenus Passiflora ( $P$. amethystina, $P$. caerulea and $P$. edulis flavicarpa) with probes of genomic DNA from P. suberosa (subgenus Decaloba) and P. foetida (subgenus Dysosmia) (Fig. 4). The last mentioned probe was also applied on P. suberosa chromosomes (Decaloba subgenus). When the DNA probe from $P$. foetida (subgenus Dysosmia) was used on mitotic preparations of subgenus Passiflora species, uniform hybridization along entire chromosomes was found. On the other hand, the same probe applied on P. suberosa (subgenus Decaloba) chromosomes showed weak hybridization signals focused in some centromeres and secondary constrictions. Hybridization of $P$. suberosa genomic DNA on mitotic preparations of $P$. amethystina, P. caerulea and P. edulis, from subgenus Passiflora, showed weaker dispersed hybridization signals over some chromosomes, on centromeres and secondary constrictions (Fig. 4).

\section{Discussion}

\section{Karyotypic parameters}

This work provides a classical and molecular cytogenetic characterization of fourteen species of Passiflora, the largest number of Argentinean species studied together to this day.

The chromosomal counts performed in the present work were in agreement with previous reports, confirming the presence of three basic chromosome number: $\mathrm{x}=6$ for subgenus Decaloba, $\mathrm{x}=9$ for subgenus Passiflora and $\mathrm{x}=10$ for subgenus Dysosmia (Sader et al. 2019; Coelho et al. 2016; Sühsner et al. 2016; Melo et al. 2015; Bugallo et al. 2013; Chiapero et al. 2013; Souza et al. 2008; Hansen et al. 2006; Soares-Scott et al. 2005; Muschner et al. 2003; Melo \& Guerra 2003; Souza et al. 2004; Deginani \& Escobar 2002; Melo et al. 2001; Deginani 2001; Storey 1950).

In this work, the first karyotype measurements for genotypes belonging to $P$. caerulea, P. elegans, $P$. mooreana, $P$. tenuifila, $P$. tucumanensis, $P$. misera, $P$. morifolia and P. suberosa were provided. Only 
metacentric chromosomes were observed in the karyotypes of $P$. alata, $P$. edulis and $P$. cincinnata, while previous publications on Brazilian genotypes recorded two submetacentric pairs for these species (Souza et al. 2003; Coelho et al. 2016). On the other hand, Praça et al. (2008) report only three pairs of metacentric chromosomes for $P$. edulis from other Brazilian collection sites, suggesting intraspecific polymorphisms in chromosome morphology. Although the karyotypes of the studied species of Passiflora are very symmetrical, this parameter was higher in the subgenus Passiflora, with almost exclusively metacentric chromosomes, than in the subgenera Dysosmia and Decaloba, which possess metacentric and submetacentric chromosomes.
The comparison of the haploid genome length measurements in the present work with that obtained in Brazilian genotypes, resulted in higher values than those of Souza et al. (2003) for P. alata; than those of Beena \& Beevy (2015), Cuco et al. (2003) and Coelho et al. (2016) for P. edulis f. flavicarpa; than those of Cuco et al. (2003) and Coelho et al. (2016) for P. cincinnata and that of Cuco et al. (2003) for P. amethystina. On the other hand, our measurement of the haploid genome of $P$. capsularis resulted in values lower than those found by Amorim et al. (2014). The variation founded in the lengths of haploid genomes between different authors could arise from differences in chromosome condensation or could represent
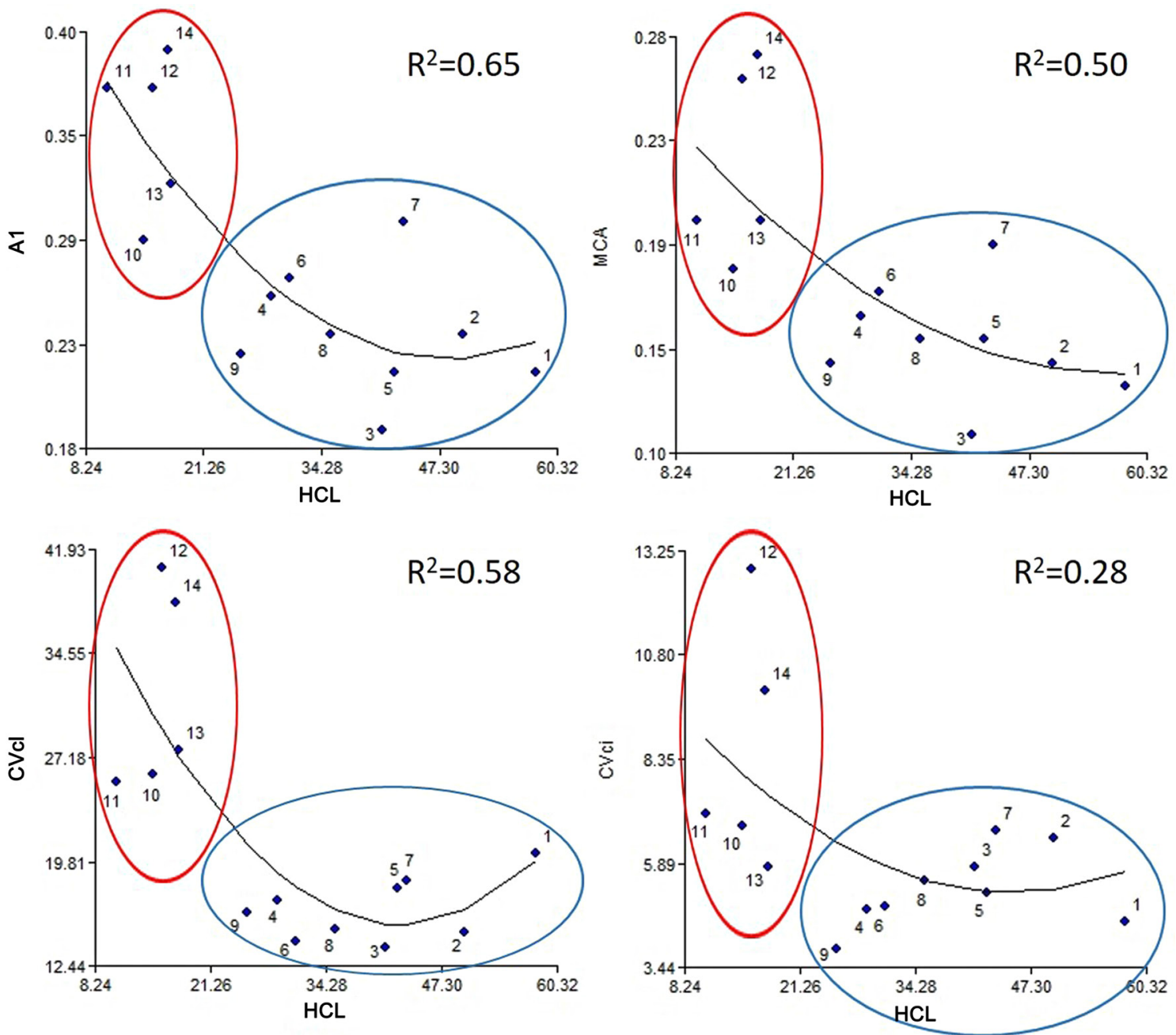

Figure 3 - Regression between asymmetry indices and the length of the haploid genome in genus Passiflora. $1=P$. alata $; 2=P$. amethystina $;=P$. caerulea $;=P$. cincinnata $; 5=P$. edulis f. flavicarpa $; 6=P$. elegans $; 7=P$. mooreana; $8=$ P. tenuifila $; 9=P$. tucumanensis $; 10=P$. foetida $; 11=P$. capsularis $; 12=$ P. misera $; 13=P$. morifolia $; 14=P$. suberosa. Red circle: subgenera Decaloba and Dysosmia $(\mathrm{x}=6$ and $\mathrm{x}=10)$; blue circle: subgenus Passiflora $(\mathrm{x}=9)$. 


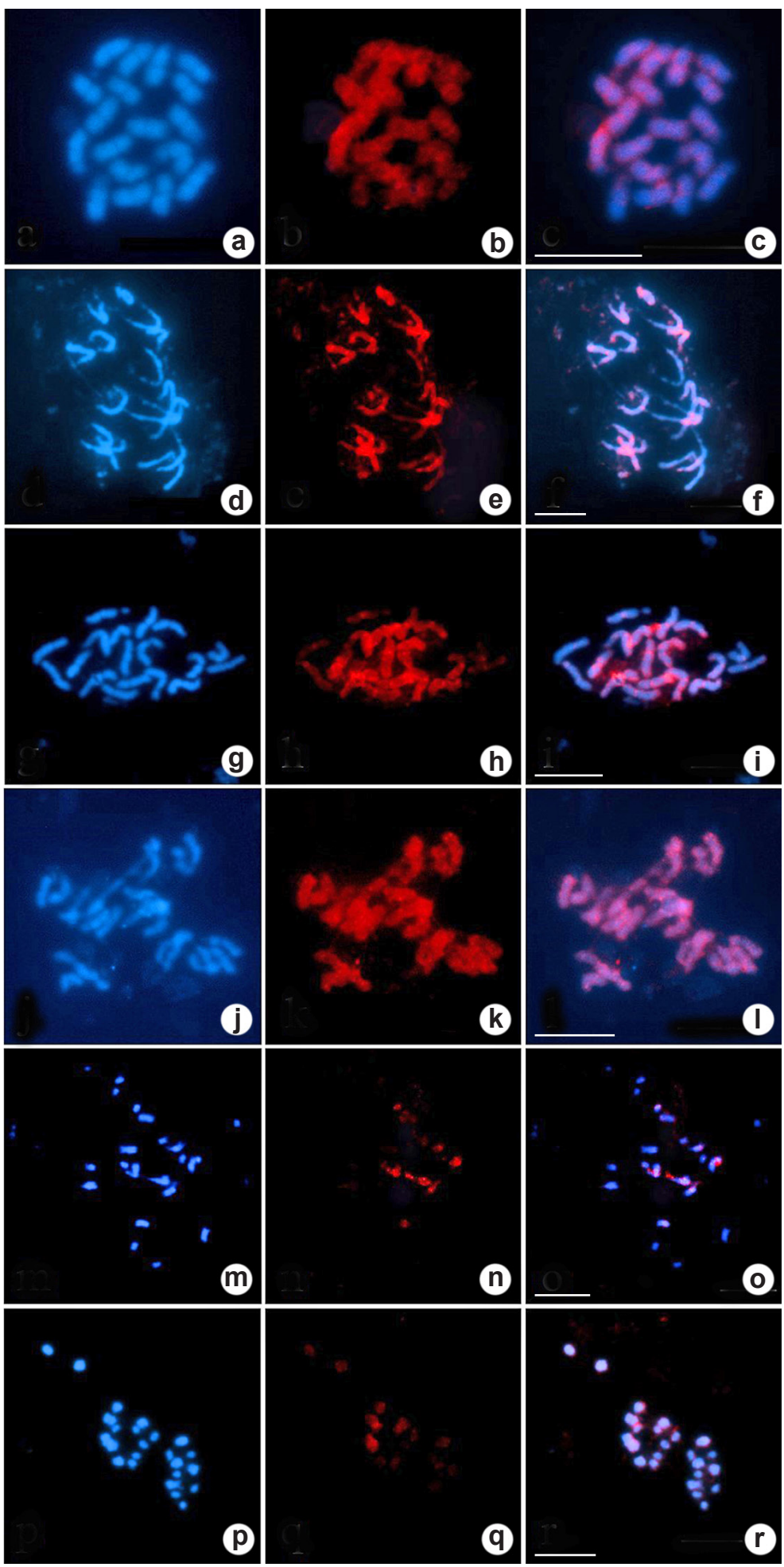

Figure 4 - a-c. Passiflora suberosa prove (subgenus Decaloba) on mitotic chromosomes of P. caerulea (subgenus Passiflora); d-f. Passiflora suberosa prove on mitotic chromosomes of P. edulis f. flavicarpa (subgenus Passiflora); g-i. Passiflora suberosa prove on mitotic chromosomes of $P$. amethystina (subgenus Passiflora); j-1. Passiflora foetida (subgenus Dysosmia) prove on mitotic chromosomes of $P$. amethystina (subgenus Passiflora); m-r. Passiflora foetida prove on mitotic chromosomes of P. suberosa (subgenus Decaloba). 
variability in the genome size among populations of the same species. A regression test among haploid chromosome lengths and published values of $1 \mathrm{C}$ genome size for eight of the studied species (Sader et al. 2019) showed a close correlation $\left(\mathrm{R}^{2}=0.96\right)$. In addition, Bugallo et al. (unpublished data) found a close relationship between the length of the haploid genome and the amount of DNA in some genotypes studied in the present work.

The regression tests between the haploid chromosome length (HCL) and the asymmetry indices $\mathrm{A} 1, \mathrm{CVcl}$ and $\mathrm{MCA}$ not only show that species with longest genomes have more symmetrical karyotypes but also exhibit similarity among the karyotype of $P$. foetida (subgenus Dysosmia) and the species of the subgenus Decaloba, both in haploid chromosome length and in karyotypic symmetry (Fig. 3).

\section{Ribosomal DNA sites}

The number of sites $5 \mathrm{~s}$ coincided with the ploidy level in Decaloba and Passiflora subgenus, showing two signals in somatic cells of the genotypes recognized as diploids and four of them in the tetraploids. On the other side, $P$. foetida is a diploid that showed four marks. These results could suggest the occurrence of polyploidy with the possibility of an ancestor $\mathrm{x}=5$, but no species related to this number is known to date, although it could also arise from an amplification of this sequence.

The results found within the Passiflora subgenus indicate that the number of $18 \mathrm{~s}$ signals would match the phylogeny based on internal transcribed spacers and plastid spacers trnL-trnF elaborated by Muschner et al. (2003). These authors placed in the same clade four species with six $18 \mathrm{~s}$ signals, $P$. caerulea, $P$. amethystina, $P$. elegans and P. tenuifila. However, Sader et al. (2019) did not include $P$. elegans in this group. Muschner et al. (2003) grouped in a clade the three species showing four 18s signals: $P$. alata, $P$. cincinnata and $P$. edulis. Sader et al. (2019) also include $P$. foetida, which presented 6 marks.

While Coelho et al. (2016) coincided with us in the number of $5 \mathrm{~s}$ signals for $P$. edulis and $P$. cincinnata and Praça et al. (2008) does it in the number of $18 \mathrm{~s}$ signals for $P$. edulis. The first authors found an extra pair of $45 \mathrm{~s}$ signals for both of these species (unit $45 \mathrm{~s}$ includes $18 \mathrm{~s}$ sequence). The variation in the number of rDNA zones could be due, among others, to the amplification and jumping to different chromosomal sites (Schubert \& Wobus 1985).
Genomic affinity among subgenera

The GISH technique allows comparing the genomic affinity between two species. Applying GISH with the use of probes of species belonging to one subgenus on the chromosomes of species from another subgenus, the zones with shared repetitive sequences could be exhibited. In mitotic preparations of species of the subgenus Passiflora, the genomic probe of $P$. foetida (subgenus Dysosmia) showed complete homology in all the chromosomes while probes of $P$. suberosa (subgenus Decaloba) showed scattered signals along the chromosomes. This would support the results of the molecular phylogenies of Muschner et al. (2003) and Sader et al. (2019) in which they affirm that there would be more phylogenetic proximity between the subgenus Dysosmia ( $P$. foetida) and the subgenus Passiflora than between the latter subgenera with respect to the subgenus Decaloba, to which $P$. suberosa belongs.

The genomic probe of $P$. foetida from subgenus Dysosmia, with $\mathrm{x}=10$, only partially marked six to eight chromosomes in the mitotic preparations of $P$. suberosa $(2 \mathrm{n}=24 ; \mathrm{x}=6)$ from subgenus Decaloba. Melo \& Guerra (2003) proposed that $P$. foetida has a later origin than the species of $\mathrm{x}=6$, the hybridization signals in only six to eight chromosomes of $P$. suberosa suggest a possible affinity with a shared ancestral genome of $\mathrm{x}=6$. One of the difficulties of working with these subgenera is the small size of their chromosomes that makes it difficult to visualize the hybridization signals.

\section{Concluding remarks}

The data obtained in this work support the hypotheses formulated by Melo et al. (2001) and Melo \& Guerra (2003). In their works, the authors propose that $\mathrm{x}=6$ would be the original basic chromosomal number of the Passifloraceae family and that the basic numbers derived from it would have occurred due to processes of dysploidy and polyploidy. According to the results obtained in the present work regarding the number of rDNA sites, karyotypes and size of basic chromosomal complements, we agree with these authors hypothesis on the evolutionary history of the genus Passiflora. They state that $\mathrm{x}=6$ is the basic genome because they have only one $5 \mathrm{~s}$ rDNA site per genome, which is supported by our FISH results. The original basic number (present in this work in diploid species as P. morifolia, P. misera and $P$. capsularis) would derived by polyploidy in another 
$\mathrm{x}=6+6, \mathrm{n}=12$, presenting four $5 \mathrm{~s}$ DNAr marks (like $P$. suberosa). Then, by descending dysploidy, $2 \mathrm{n}=24$ could generate $2 \mathrm{n}=20, \mathrm{x}=10$, keeping the four DNAr signals ( $P$. foetida) and, by another event of descending dysploidy, $\mathrm{x}=9$ (P. alata, $P$. amethystina, $P$. caerulea, among others) $(\mathrm{x}=6 \mathrm{a}$ $x=12$ a $x=10 a x=9$ ) (Fig. 5). We find that this hypothesis explain in a more parsimonious way the chromosomal evolutionary process than that exposed by Sader et al. (2019). They affirm that the genome evolved by ascending dysploidy ( $\mathrm{x}$ $=6 \mathrm{ax}=7-8$ a $\mathrm{x}=9 \mathrm{ax}=10)$, generating in the last instance, the basic number $x=10$. Although this option is possible, the fact of not knowing any Passiflora species with intermediate basic numbers $\mathrm{x}=7$ or $\mathrm{x}=8$ make it less parsimonious. These authors also discuss prediction models, questioning the validity of some of the algorithms applied for evolutionary studies. In addition, it is necessary to take into account that $P$. foetida $(\mathrm{x}=10)$ is the most variable species of the whole genus with almost 50 varieties dispersed not only in America but also in Africa, Southeast Asia and Australia (Ulmer \& MacDougal 2004).

The work of "molecular clock" by Muschner et al. (2012) shows that the diversification of the subgenus Decaloba, with $\mathrm{x}=6$, would have occurred 29 million years ago while that of the subgenus Passiflora, with $\mathrm{x}=9$, would have done it almost 17 million years ago. Unfortunately, neither Muschner et al. (2012) nor the Sader et al. (2019) studies included other representatives of basic number $\mathrm{x}=10$, such as $P$. chrysophylla, $P$. arida, $P$. pectinata, $P$. sublanceolata and $P$. urbaniana, among others. In the present work, we found $P$. foetida (subgenus Dysosmia) more related to the species of the subgenus Passiflora than to those of the subgenus Decaloba. On the other hand, the karyotype characteristics and the length of the haploid genome were strikingly similar between the subgenera Dysosmia and Decaloba. For this reason, we support the hypothesis that $P$. foetida $(\mathrm{x}=10)$ would be an actual species related to the one that link the original subgenera Decaloba (x $=6)$ and Passiflora $(\mathrm{x}=9)$, as formulated by Melo et al. (2001).

In general terms, the growth in size of a genome could become from both polyploidy events and amplification of transposable elements (Bennetzen et al. 2005). According to these authors, there would be the possibility that some species show greater activity of one of the mechanisms of genomic size variation, being able to grow more than decrease their genome. The species evaluated in this work with chromosome basic number $\mathrm{x}=9$ possess the longest genomes of the genus, suggesting that the process of descending dysploidy (which reduced the basic number $\mathrm{x}=10$ to $x=9$ ) was accompanied by an increase in the DNA content that is reflected in the chromosomal length of the subgenus Passiflora. In the case of this subgenus, the responsible for the amplification of the genome would be the activation of transposable elements.

The distribution of DNA among chromosome arms could derive in changes in the karyotype intrachromosomal and interchromosomal asymmetry (Peruzzi et al. 2009; Peruzzi \& Eroglu 2013). Sometimes, the same amount of DNA is added to each chromosome arm (equal increase),

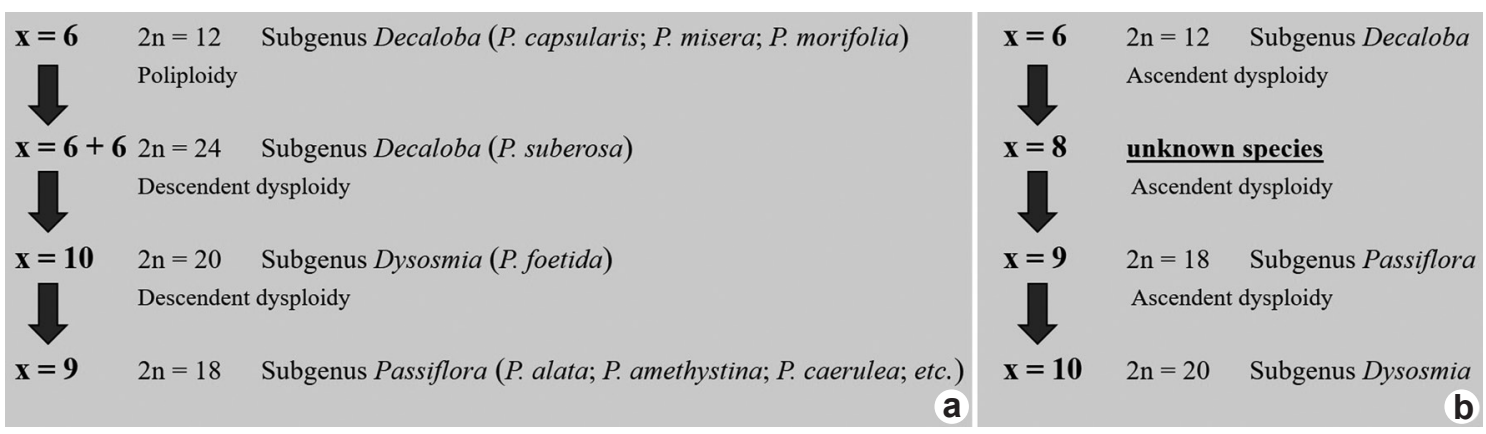

Figure 5 - a-b. Hypothesized chromosomic evolutionary process of genus Passiflora - a: hypothesis proposed by Melo et al. (2001) and Melo \& Guerra (2003) supported by this work: original basic number $\mathrm{x}=6$ undergoes a polyploidy event that generates an $\mathrm{x}=6+6,2 \mathrm{n}=24$, by descending dysploidy it would produce $2 \mathrm{n}=20, \mathrm{x}=10$ and by another event of descending dysploidy $\mathrm{x}=9$; $\mathrm{b}$. hypothesis proposed by Sader et al. (2019): basic number $\mathrm{x}=6$ would suffer several events of ascending dysploidy originating basic number $\mathrm{x}=7-8,9$ and 10 . 
resulting in an increase in the intrachromosomal karyotype symmetry. In other cases, the amount of DNA added is different between chromosome arms (unequal increase), resulting in a decrease of the intrachromosomal symmetry (Poggio et al. 2014). The highly symmetrical karyotypes in the subgenus Passiflora associated with the longest genomes of the genus suggest that the pattern of DNA accumulation caused an unequal increase in both chromosomal arms. The karyotypes of $x=9$ were the most symmetrical, presented more DNA and longest genomes suggesting that, if they derive from $x=6$, the rearrangements involved in the establishment of $x=9$ caused genomic obesity and that the distribution of repetitive DNA was unequal being greater in the short arms and leading to more symmetrical karyotypes.

In summary, the karyotypic parameters studied in 14 species as well as the genomic affinities among different species belonging to subgenus Decaloba, Dysosmia and Passiflora clarify most of the chromosomal evolution of the genus and provides information to be applied in the breeding program.

The data obtained lead to confirm previous data and strongly suggest that the basic number $\mathrm{x}=6$ would be the original one, and that $\mathrm{x}=9$ was originated by processes of polyploidy and descendent dysploidy. The high molecular affinity between subgenus Dysosmia ( $P$. foetida) and species of the subgenus Passiflora supports their closeness but it does not clarify which of the two originated the other. Since the genus Passiflora possesses the longest genomes, it is postulated that evolutionary process leading $\mathrm{x}=10$ to $\mathrm{x}=9$ was accompanied by unequal distribution of non-coding repetitive DNA, mainly transposable elements. These processes could explain the assymetrical karyotypes of species of subgenus Passiflora.

\section{Acknowledgements}

The authors would like to thank Mrs. Ema Coll for reviewing the English language and to the editors for their valuable contribution to improve this work.

\section{References}

Amorim JDS, Souza MM, Viana AJC, Correa RX, Araújo IS \& Ahnert D (2014) Cytogenetic, molecular and morphological characterization of Passiflora capsularis L. and Passiflora rubra L. Plant Systematics and Evolution 300: 1147-1162.
Beena VL \& Beevy SS (2015) Genetic diversity in two species of Passiflora L. (Passifloraceae) by karyotype and protein profiling. Nucleus 58: 101106.

Bennetzen JL, Ma J \& Devos KM (2005) Mechanisms of recent genome size variation in flowering plants. Annals of Botany 95: 127-132.

Bugallo V, Cardone S, Pannunzio MJ, Coviella A, Facciuto G (2013) Chromosome studies and the implications on ornamental characteristics in Passiflora mooreana (Passifloraceae). Acta Horticulturae, Internacional Society for Horticultural Science 1000: 131-135. ISSN: 0567-7572.

Bugallo V, Cardone S, Pannunzio MJ \& Facciuto G (2011) Breeding advances in Passiflora (passionflower) native from Argentina. Global Science Books 5: 23-34.

Chiapero AL, Las Peñas ML, García MTA \& Bernardello G (2013) Estudios citogenéticos en especies de Passiflora subgénero Passiflora (Passifloraceae). Boletín de la Sociedad Argentina de Botánica 48: 103-110.

Coelho MDSE, Bortoleti KCA, Araújo FP \& Melo NF (2016) Cytogenetic characterization of the Passiflora edulis Sims x Passiflora cincinnata Mast. Interspecific hybrid and its parents. Euphytica 210: 93-104.

Cuco SM, Mondin M, Vieira MLC \& Aguiar-Perecin MLR (2003) Técnicas para a obtenção de preparações citológicas com alta frequência de metáfases mitóticas em plantas: Passiflora (Passifloraceae) e Crotalaria (Leguminosae). Acta botanica Brasilica 17: 363-370.

Deginani N (2001) Las especies argentinas del género Passiflora. Darwiniana 39: 43-129.

Deginani N \& Escobar (2002) Números cromosómicos de especies de Passiflora (Passifloraceae). Hickenia 3: 143-144.

Hansen AK, Gilbert LE, Simpson BB, Downie SR, Cervi AC \& Jansen RK (2006) Phylogenetic relationships and chromosome number evolution in Passiflora. Systematic Botany 31: 138-150.

Levan A, Fredga K \& Sandberg A (1964) Nomenclature for centromeric position on chromosomes. Hereditas 52: 201-220.

Melo CAF, Silva GS \& Souza MM (2015) Establishment of the genomic in situ hybridization (GISH) technique for analysis in interspecific hybrids of Passiflora. Genetics and molecular research 14: 2176-2188.

Melo NF, Cervi AC \& Guerra M (2001) Karyology and cytotaxonomy of the genus Passiflora. Plant systematics and evolution 226: 69-84.

Melo NF \& Guerra M (2003) Variability of the 5s and $45 \mathrm{~s}$ sites in Passiflora L. species with distinct base chromosome numbers. Annals of Botany 92: 309-316.

Muschner VC, Lorenz AP, Cervi AC, Bonatto SL, Souza-Chies TT, Salzano FM \& Freitas LB 
(2003) A first molecular phylogenetic analysis of Passiflora (Passifloraceae). American Journal of Botany 90: 1229-1238.

Muschner VC, Zamberlan PM, Bonatto SL \& Freitas LB (2012) Phylogeny, biogeography and divergence times in Passiflora (Passifloraceae). Genetics and Molecular Biology 35: 1036-1043.

Paszko A (2006) A critical review and a new proposal of karyotype asymmetry indices. Plant Systematics and Evolution 258: 39-48. DOI: 10.1007/s00606005-0389-2

Peruzzi L \& Eroglu HE (2013) Karyotype asymmetry: again, how to measure and what to measure? Comparative Cytogenetics 7: 1-9.

Peruzzi L, Leitch IJ \& Caparelli KF (2009) Chromosome diversity and evolution in Liliaceae. Annals of Botany 103: 459-475.

Poggio L, Realini MF, Fourastié MF, García AM \& González GE (2014) Genome downsizing and karyotype constancy in diploid and polyploid congeners: a model of genome size variation. AoB Plants 6. Available at <https://doi.org/10.1093/ aobpla/plu029>.

Praça MM, Carvalho CR, Marcelino FC \& Mendonça MAC (2008) Mophological aspects of Passiflora edulis $f$. flavicarpa chromosomes using acridine orange banding and rDNA-FISH tools. Caryologia 61: 154-159.

Realini MF (2017) Variabilidad citogenética de los maíces Guaraníes del Noreste de Argentina: caracterización cariotípica, tamaño del genoma y correlatos fenotípicos. Doctoral Thesis. Universidad de Buenos Aires-UBA, Buenos Aires. 208p.

Romero Zarco C (1986) A new method for estimating karyotype asymmetry. Taxon 35: 526-530.

Sader MA, Amorim BS, Costa L, Souza G \& Pedrosa-
Harand A (2019) The role of chromosome changes in the diversification of Passiflora L. (Passifloraceae). Systematics and Biodiversity 0: 1-15.

Schubert I \& Wobus U (1985) In situ hybridization confirms jumping nucleolus organizing regions in Allium. Chromosoma 92: 143-148.

Soares-Scott MD, Meletti LM, Bernacci LC \& Passos IRS (2005) Citogenética clássica e molecular em passifloras. In: Faleiro FG, Junqueira NTV \& Braga MF (eds.) Maracujá: germoplasma e melhoramento genético. Embrapa Cerrados, Planaltina. Pp. 210240.

Souza MM, Palomino G, Pereira TNS, Pereira MG \& Viana AP (2004) Flow cytometric análisis of genome size variation in some Passiflora species. Hereditas 141: 31-38.

Souza MM, Palomino G, Pereira TNS \& Vieira MLC (2008) Cytogenetic studies in some species of Passiflora: a review emphasizing Brazilian species. Brazilian Archives of Biology and Technology 51: 247-258.

Souza MM, Pereira TNS, Silva LC, Reis DSS \& Sudré CP (2003) Karyotype of six Passiflora species collected in the state of Rio de Janeiro. Cytologia 68: 165-171.

Storey WB (1950) Chromosome numbers of some species of Passiflora occurring in Hawaii. Pacific Science 4: 37-42.

Sühsner CP, Honfi AI, Ferrucci MS \& Deginani N (2016) Microsporogénesis de tres especies del subgénero Passiflora (Passifloraceae) de Paraguay. Darwiniana 4: 45-56.

Sumner AT (1990) Chromosome banding. Unwin Hyman, London. 434p.

Ulmer T \& MacDougal JM (2004) Passiflora: passionflowers of the World. Timber Press, Cambridge. Pp. 1-430. 